\title{
Penerapan Model Pembelajaran Aptitude Treadmen Interaction (ATI) Dalam Meningkatkan Aktifitas Dan Hasil Belajar Matematika
}

\author{
Anhar Kurniawana, $1^{*}$ \\ aSMPN 2 Jatipurno, Kecamatan Jatipurno, Kabupaten Wonogiri, Jawa Tengah, Indonesia \\ ${ }^{1}$ Anharkurniawan01@gmail.com* \\ * Corresponding Author
}

Diterima 17 Februari 2021; Disetujui 16 Maret 2021; Diterbitkan 17 Maret 2021

\begin{abstract}
This is a classroom action research. Classroom action research is an effort that researchers can make to improve the quality of the roles and responsibilities of educators, especially in the management of learning. The objective of this study is to improve learning activities and mathematics learning outcomes through the Aptitude Treatment Interaction (ATI) learning model for eighth grade students of SMP Negeri 2 Jatipurno, Wonogiri on academic year 2018/2019. The data collection methods are questionnaires, documentation of learning outcomes. The validity of the data use triangulation techniques. Learning Model Aptitude Treatment Interaction (ATI) with a discussion process with several study groups that have been grouped based on similarities in average abilities. Based on data analysis from two cycles, it can be concluded that this study has an increase in student learning activities so that it affects the learning process and student learning outcomes also have a significant increase.
\end{abstract}

KEYWORDS

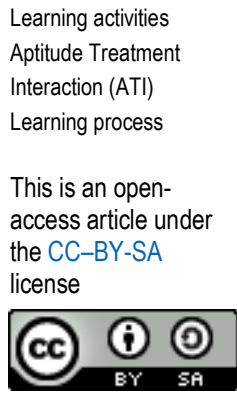

Learning activities Aptitude Treatment interaction (ATI) ( the CC-BY-SA BY $S A$

\section{Pendahuluan}

Pada jaman globalisasi seperti saat ini, bangsa Indonesia memerlukan generasi pembangunan yang berkualitas. Bidang pendidikan merupakan salah satu prasarana yang paling efisien untuk meningkatkan kualitas sumber daya manusia. Oleh karena itu, pemerintah berupaya memberikan perhatian khusus terhadap bidang pendidikan. Diharapkan dapat meningkatkan kualitas sumber daya manusia Bangsa Indonesia, sehingga dapat mengikuti ilmu pengetahuan dan teknologi yang semakin maju maka Bangsa Indonesia dapat sejajar dengan negara maju yang lain.

Keberhasilan prestasi peserta didik dipengaruhi oleh dua faktor, yaitu faktor dari dalam dan faktor dari luar diri peserta didik. Faktor dari dalam dapat berupa kecerdasan, minat, bakat, motivasi, kepribadian. Minat belajar merupakan modal awal siswa untuk belajar, minat belajar merupakan dorongan dari dalam diri siswa secara psikis untuk mempelajari sesuatu dengan kesadaran, ketenangan dan kedisiplinan, sehingga siswa dapat secara aktif dan senang untuk melakukannya. Minat belajar matematika siswa masih perlu ditingkatkan, untuk meningkatkan minat belajar dapat melalui suatu pembelajaran yang aktif, kreatif dan inovatif yang dapat meningkatkan minat belajar matematika siswa (Aedi 2018). Minat belajar yang tinggi akan memudahkan siswa mencapai tujuan belajar (Haryadi and Andriati 2019). Penentuan minat dan bakat perlu dilakukan untuk dapat mengetahui suatu keterampilan pada peserta didik, baik dalam segi akademis maupun kepribadian (Rachman and Mukminin 2018; Supardi 2014). Dilain sisi kemampuan berpikir kritis siwa merupakan kemampuan yang sangat esensial untuk kehidupan, pekerjaan, pembelajaran dan berfungsi efektif dalam semua aspek kehidupan ini juga merupakan faktor yang mempengaruhi keberhasilan dari dalam siswa (Masni, 2019; Sembiring, 2013). Dari penelitian Nurhidayah menunjukkan bahwa "motivasi berprestasi tinggi memberikan prestasi belajar yang lebih baik daripada motivasi berprestasi sedang, motivasi berprestasi tinggi memberikan prestasi belajar yang lebih baik daripada motivasi berprestasi rendah, motivasi berprestasi sedang memberikan prestasi belajar yang lebih baik daripada motivasi berprestasi 
rendah" (Nurhidayah 2015; Lestari 2017). Faktor keberhasilan dari dalam siswa yang terakhir adalah kepribadian, kepribadian siswa mempengaruhi output mereka ketika memecahkan masalah (Widayanti 2016). Perbedaan kepribadian dimungkinkan berpengaruh pada kemampuan penalaran matematis siswa, kemampuan penalaran matematis siswa bertipe kepribadian artisan dan rational adalah mampu menyajikan pernyataan matematika dalam bentuk grafik dengan baik, mampu mengajukan dugaan/konjektur tetapi tidak mampu melakukan pengujian dengan benar, mampu menentukan pola/hubungan secara parsial, mampu melakukan manipulasi matematika dengan baik dan benar, mampu memberikan alasan secara parsial, mampu memeriksa kesahihan terhadap pernyataan, tetapi disisi lain siswa artisan dan rational tidak mampu menarik simpulan dengan tepat (Dwiningrum and Pramudya 2016; Kiswanto, Rahman, and Sulasteri 2015).

Sedangkan faktor dari luar dapat berupa fasilitas belajar, lingkungan keluarga, lingkungan sekolah dan lingkungan masyarakat. Fasilitas belajar berpengaruh secara langsung terhadap prestasi belajar (Sawiji, Martono, and Inayah 2013). Kelengkapan fasilitas belajar di rumah dan penggunaan waktu belajar di rumah mempengaruhi prestasi belajar (Bangun 2012). Fasilitas belajar memiliki pengaruh yang positif dan signifikan terhadap prestasi belajar siswa, baik secara parsial maupun simultan. Oleh karena itu, prestasi belajar siswa dapat ditingkatkan melalui peningkatan cara belajar dan fasilitas belajar (Febriani and Sarino 2017). Faktor yang lain adalah karakter siswa yang berkualitas diperlukan pengaruh yang kuat dari keluarga, sekolah, dan mayarakat (Subianto 2013). Peranan lingkungan sosial juga memiliki peranan penting terhadap pembentukan sikap peduli lingkungan peserta didik, adapun lingkungan sosial yaitu lingkungan keluarga, sekolah, masyarakat (Kurniawan and Wustqa 2014; Tamara 2016).

Pelajaran matematika merupakan salah satu pelajaran yang penting bagi peserta didik. Namun, pelajaran matematika juga merupakan salah satu pelajaran yang paling ditakuti, karena banyak yang menganggap matematika pelajaran yang sulit untuk dikuasai. Kegiatan proses belajar mengajar dengan menggunakan metode konvensional masih didominasi oleh guru, sehingga siswa hanya duduk mendengarkan, meniru pola-pola yang diberikan guru, mencontoh cara yang diberikan oleh guru untuk menyelesaikan soal-soal yang pada akhirnya ini akan membuat siswa menjadi pasif.

Salah satu masalah dalam pengajaran matematika yaitu masih rendahnya prestasi belajar siswa. Peran guru sangat penting dalam pelaksanaan proses pembelajaran untuk mencapai prestasi belajar (Styawan, Susilowati, and Wulandari 2019). Rendahnya prestasi belajar siswa ini mungkin dikarenakan kurang tepatnya pemilihan metode mengajar yang digunakan guru dalam menyampaikan suatu pokok bahasan. Sehingga perlu adanya peningkatan aktivitas belajar siswa meliputi peningkatan aktivitas bertanya, mengemukakan pendapat menanggapi jawaban, serta mengurangi aktivitas lain diluar proses pembelajaran juga merupakan bentuk peningkatan hasil belajar (Bachtiar 2017; Hidajat, Amin, and Fuad 2018). Hasil belajarmerupakan prestasi belajar yang dicapai siswa dalam proses kegiatan belajar mengajar dengan membawa suatu perubahan dan pembentukan tingkah laku seseorang (Anggo et al., 2014; Hidajat, Wulandari, \& Susilowati, 2018).

Berkaitan dengan hal tersebut, permasalahan yang sama terjadi di SMP Negeri 2 Jatipurno di mana kegiatan pembelajaran berpusat pada guru sehingga sebagian besar siswanya menjadi pasif dan tidak terlibat aktif. Melalui wawancara kepada guru kelas VIII SMP Negeri II Jatipurno, didapatkan bahwa KKM mata pelajaran matematika di sekolah tersebut 700,00. Namun hasil menunjukkan baru 40\% siswa yang tuntas melebihi KKM dari total 24 siswa.

Dari uraian di atas penulis merasa tertarik untuk menerapkan salah satu metode pembelajaran sebagai alternatif pemecahannya. Metode pembelajaran yang dimaksud yaitu model pembelajaran Aptitude Tredmen Interaction (ATI) dimana metode pembelajaran ini memberikan waktu lebih banyak untuk siswa berfikir, menjawab, dan saling membantu satu sama lain. Dari penelitian Abu, Fitri, dan Herlina menyimpulkan bahwa terdapat perbedaan hasil belajar matematika setelah penerapan model pembelajaran Aptitude Treatment Interaction (ATI) dimana lebih berpengaruh pada kelas kecil dibandingkan pada kelas besar (Abu Bakar, Nursalam, and Mardhiah 2016; Fitri 2017; Herlina 2015). 
Berdasarkan uraian di atas maka peneliti terdorong untuk melakukan penelitian dengan menggunakan model pembelajaran Aptitude Tredmen Interaction (ATI) dalam pembelajaran matematika siswa kelas VIII di SMP Negeri 2 Jatipurno Kabupaten Wonogiri.

\section{Metode}

Pendekatan penelitian tindakan yang digunakan dalam pemecahan masalah ini adalah Penelitian Tindakan Kelas (PTK). Penelitian tindakan kelas merupakan suatu pencermatan terhadap kegiatan yang sengaja dimunculkan dan terjadi dalam sebuah kelas. Penelitian tindakan kelas sebetulnya tidak sulit, karena guru tinggal melakukan dengan segaja dan diamati hasilnya secara seksama.

Penelitian Tindakan Kelas (PTK) ini dilaksanakan di SMP N 2 Jatipurno Kabupaten Wonogiri semester genap tahun ajaran 2018/2019. Subjek penelitian tindakan kelas ini adalah siswa kelas VIII SMP Negeri II Jatipurno tahun ajaran 2018/2019, sebanyak 27 siswa yang terdiri dari 10 siswa laki-laki dan 17 siswa perempuan.

Rencana penelitian ini berupa prosedur kerja dalam suatu penelitian tindakan kelas yang secara bertahap dan dilakukan beberapa siklus. Setiap siklus meliputi tahapan-tahapan antara lain: tahap perencanaan, tahap pelaksanaan, tahap pengamatan dan refleksi. Tahapan tersebut disusun dalam suatu siklus.

Bagan Rancangan Penelitian digambarkan dalam Gambar 1.

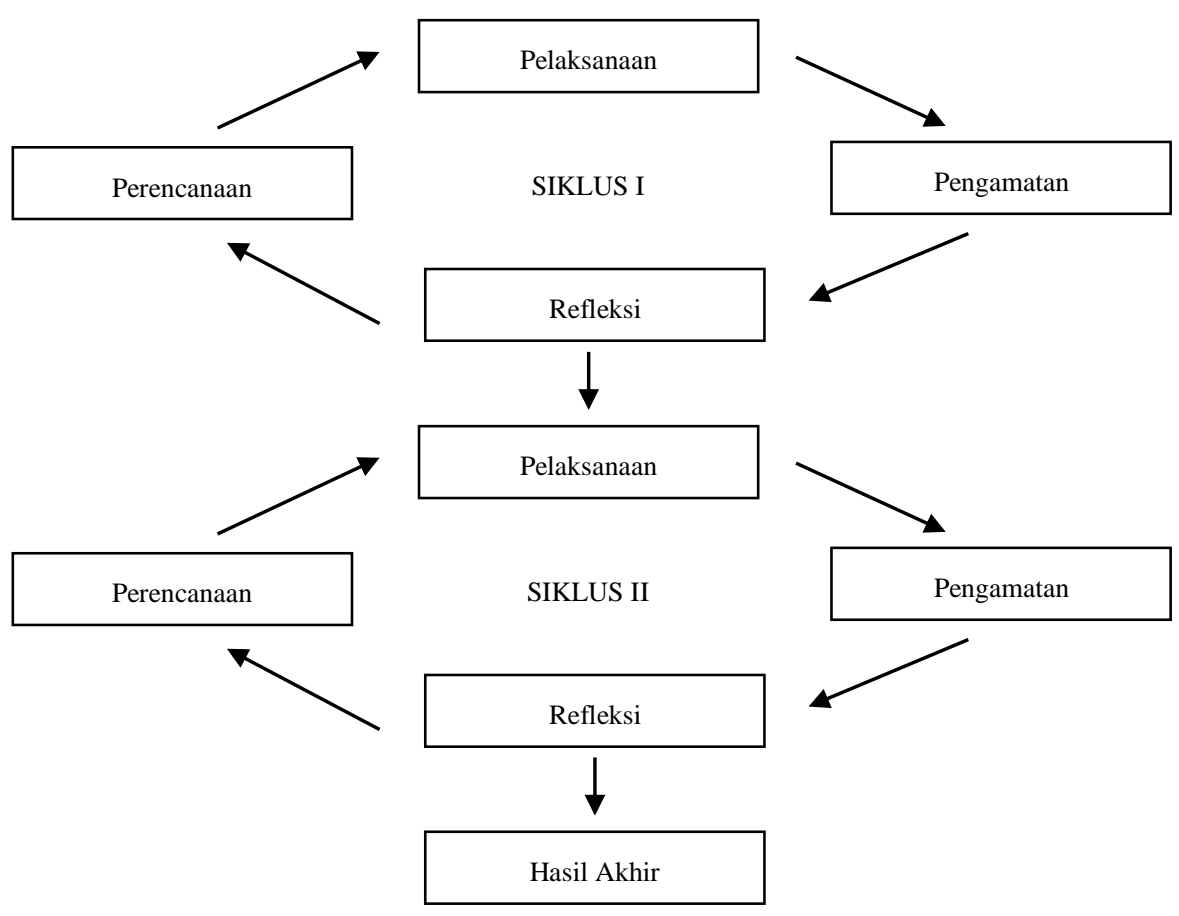

Gambar 1. Bagan Rancangan Penelitian

Penelitian ini dilakukan dengan cara mengadakan penelitian tindakan kelas yang ditempuh secara bertahap. Penelitian ini direncanakan dalam dua siklus, tetapi bila siklus II prestasi belajar siswa belum mencapai indikator maka dilanjutkan pada siklus selanjutnya. Masing-masing siklus terdiri dari 4 tahap yaitu perencanaan, pelaksanaan, pengamatan dan refleksi.

Pada perencanaan siklus I, peneliti telah berkoordinasi dengan kepala sekolah dan siswa dan dilanjutkan dengan membuat Rencana Pelaksanaan Pembelajaran (RPP) yang menggunakan metode pembelajaran ATI (Aptitude Tredmen Interaction). Peneliti menyiapkan blangko nilai, materi untuk pelaksanaan kegiatan belajar mengajar dan menyusun soal test. 
Pada tahap tindakan, peneliti yang berperan sebagai guru menyampaikan materi pelajaran yang didalamnya memberikan apersepsi dan motivasi kepada siswa dalam mempelajari materi. Para siswa dibagi menjadi beberapa tim. dan diberikan tes pra-program pada permulaan pelaksanaan program. Mereka ditempatkan pada tingkat yang sesuai dengan hasil dalam tes ini. Para siswa diberikan tempat untuk memulai dalam unit matematika individual. Unit tersebut tertera pada buku-buku siswa. Siswa mengerjakan soal yang kemudian dicek oleh temannya. Di akhir pembelajaran, guru memberikan ulasan terhadap seluruh jawaban yang diberikan peserta didik, selanjutnya bersama-sama peserta didik merumuskan kesimpulan.

Tahap observasi dilakukan selama proses pembelajaran. Hal-hal yang diamati selama proses pembelajaran adalah kegiatan pembelajaran dan aktivitas guru maupun siswa selama pelaksanaan pembelajaran. Kegiatan pada tahap refleksi adalah memperhatikan hasil tes tertulis berdasarkan hasil pengamatan.

Pada perencanaan siklus II, peneliti membuat perencanaan tindakan berdasarkan refleksi pada siklus I. Dalam pelaksanaan tetap menggunakan media kotak imajinasi dan tidak jauh berbeda dengan siklus I yang menjadi penekanan pada siklus II adalah siswa yang belum mencapai KKM. Selanjutnya peneliti mengamati siswa dalam mengerjakan soal yang telah diberikan oleh peneliti dan memberikan bimbingan kepada siswa yang belum tuntas KKM. Observer mengamati proses pembelajaran dan membuat refleksi siklus II. Dari hasil refleksi tersebut, peneliti kemudian membuat kesimpulan sementara, karena dianggap sudah berhasil atau memenuhi target maka perbaikan pembelajaran berakhir pada siklus II.

\section{Hasil dan Pembahasan}

Berdasarkan hasil tes pra siklus menunjukkan bahwa hasil belajar siswa masih rendah. Hal tersebut ditunjukkan dari 27 siswa yang duduk di kelas VIIID, masih ada 13 siswa (48\%) mendapatkan nilai di bawah KKM (60) atau persentase ketuntasan hanya mencapai 52\% dengan nilai rata-rata kelas 58,2 .

Pada siklus pertama, nilai terendah meningkat sebesar 10,0 dari 40 menjadi 50. Nilai tertinggi meningkat 10,0 dari 80 menjadi 90. Nilai rata-rata meningkat sebesar 7,41 dari 59,2 menjadi 67,03 sedangkan ketuntasan meningkat dari 11 siswa menjadi 17 siswa. Dari data tersebut diperoleh informasi bahwa terjadi peningkatan pencapaian hasil belajar oleh siswa bila dibandingkan dengan kegiatan prasiklus, tetapi belum mencapai tingkat ketuntasan sebagaimana yang telah diharapkan. Proses pembelajaran Matematika kemudian dikaji ulang (refleksi) untuk menentukan sebab-sebab ketidak tuntasan.

Hasil refleksi siklus I menunjukkan bahwa 50\% dari jumlah peserta terlibat aktif dalam materi pelajaran, 50\% siswa mampu menyelesaikan soal test formatif, 50\% siswa tuntas KKM dan 50\% siswa mendapat nilai 70 atau lebih. Pada siklus I target ketuntasan siswa belum terpenuhi karena peneliti mentargetkan $85 \%$ dari 24 siswa mendapatkan nilai 75 . Selain itu, observer mengamati beberapa siswa masih kurang dalam bekerja sama. Jiwa kompetisi masih mendominasi sehingga interaksi antara anak berkemampuan rendah dan anak berkemampuan tinggi belum terlihat dalam siklus I. Oleh karena itu, peneliti melanjutkan penelitian ke siklus II dengan lebih memberi motivasi dan pengarahan kepada siswa mengenai pentingnya kerjasama dalam pembelajaran dengan model Aptitude Tredmen Interaction (ATI).

Pada siklus kedua, nilai terendah meningkat sebesar 10,0 dari 50 menjadi 60 . Nilai tertinggi tidak ada peningkatan, tetap 90. Nilai rata-rata meningkat sebesar 6,5 dari 64,8 menjadi 71,3 sedangkan ketuntasan meningkat dari 17 siswa menjadi 22 siswa.

Hasil refleksi siklus II, menunjukkan bahwa 100\% dari 24 siswa atau 24 siswa terlibat aktif dalam proses pembelajaran, $85 \%$ dari 24 siswa atau 18 siswa mampu menyelesaikan soal tes formatif, 85\% dari 24 siswa atau 18 siswa tuntas KKM dan $85 \%$ dari 24 siswa atau 18 siswa mendapat nilai 80 atau lebih. Melihat hasil tersebut maka siklus dihentikan pada siklus II. Hasil pengamatan aktifitas belajar siswa dari kondisi awal ke kondisi akhir ditunjukkan dalam Tabel 1.

Siswa yang semangat belajar meningkat dari : 9 siswa menjadi 22 siswa, siswa yang mendengarkan penjelasan guru meningkat dari 11 siswa menjadi 21 siswa, siswa yang aktif Tanya jawab meningkat dari 10 siswa menjadi 22 siswa, siswa yang aktif bekerjasama dalam 
kelompok meningkat dari 10 siswa menjadi 23 siswa, siswa yang aktif mengerjakan tugas meningkat dari 10 siswa menjadi 23 siswa. Hasil belajar siswa dari kondisi awal ke kondisi akhir ditunjukkan dalam Tabel 2.

Tabel 1. Aktifitas belajar siswa pra siklus, siklus I, dan siklus II

\begin{tabular}{cccc}
\hline Aktifitas & Kondisi Awal & Kondisi Siklus I & Kondisi Siklus II \\
\hline Aktifitas 1 & 9 & 17 & 22 \\
Aktifitas 2 & 11 & 17 & 21 \\
Aktifitas 3 & 10 & 16 & 22 \\
Aktifitas 4 & 10 & 15 & 23 \\
Aktifitas 5 & 10 & 15 & 23 \\
Rata-rata & 37 & 64,8 & 82 \\
Kategori & Rendah & Sedang & Sangat tinggi \\
\hline
\end{tabular}

Peningkatan hasil belajar pada setiap siklusnya menunjukkan bahwa pembelajaran dengan menerapkan metode pembelajaran ATI sudah berhasil. Selain dapat meningkatkan hasil belajar siswa, metode pembelajaran ATI juga dapat memperbaiki dan meningkatkan kinerja guru serta aktifitas siswa dalam pembelajaran. Kinerja guru dalam menerapkan metode pembelajaran ATI mengalami peningkatan, yang semula kegiatan pembelajaran yang diciptakan masih bersifat klasikal dan bersifat umum dapat disajikan lebih real sesuai kehidupan sehari-hari serta setiap siswa mendapat kesempatan berdiskusi dengan teman sejawat yang sebelumnya tidak pernah dilakukan. Demikian halnya dengan aktifitas siswa, yang semula siswa kurang berani mengemukakan pendapat menjadi lebih berani dan semakin terlibat aktif dalam pembelajaran.

Tabel 2. Hasil belajar siswa pra siklus, siklus I, dan siklus II

\begin{tabular}{cccc}
\hline Hasil Ulangan Harian & Kondisi Awal & Kondisi Siklus I & Kondisi Siklus II \\
\hline Nilai terendah & 40 & 50 & 60 \\
Nilai Tertinggi & 80 & 90 & 90 \\
Nilai Rata-rata & 59,2 & 67,03 & 71,48 \\
Ketuntasan & 11 & 17 & 22 \\
\hline
\end{tabular}

\section{Simpulan}

Berdasarkan hasil penelitian yang diperoleh dapat disimpulkan bahwa penerapan Aptitude Tredmen Interaction (ATI) dapat meningkatkan aktifitas belajar dan hasil belajar matematika pada materi soal cerita khususnya pada pokok bahasan persamaan garis lurus siswa kelas VIII SMP N 2 Jatipurno. Dan hal tersebut dapat dilihat pada : 1. Kondisi awal nilai rata-rata siswa 59,62 dengan 40,7 \% siswa tuntas belajar. Pada tindakan siklus I nilai rata rata siswa 67,03 dengan 62,9\% siswa tuntas belajar. Selanjutnya pada tindakan siklus II nilai rata-rata siswa 71,48 dengan 81,4\% siswa tuntas belajar. 2. Kondisi awal rata-rata aktifitas siswa $37 \%$ dengan kategori rendah. Pada tindakan siklus I rata-rata aktifitas siswa $59 \%$ dengan kategori sedang. Selanjutnya pada tindakan siklus II rata-rata aktifitas siswa $82 \%$ dengan kategori sangat tinggi. Dari hasil pengamatan dari siklus II dapat menunjukkan bahwa indikator keberhasilan sudah tercapai.

\section{Referensi}

Abu Bakar, Ardiansyah, Nursalam Nursalam, and Mardhiah Mardhiah. 2016. "Pengaruh Model Pembelajaran Aptitude Treatment Interaction (ATI) Terhadap Hasil Belajar Matematika Siswa Ditinjau Dari Ukuran Kelas IX Sekolah Menengah Pertama (SMP) Negeri Di Kec. Pattallassang Kab. Gowa." MaPan; ISSN: 23546883. https://doi.org/10.24252/mapan.2016v4n1a4.

Aedi, Weni Gurita. 2018. “Upaya Meningkatkan Minat Belajar Matematika Dengan Pendekatan 
Open-Ended." Jurnal Pendidikan Matematika Indonesia(JPMI); p-ISSN: 2477-5967 eISSN: 2477-8443 3 (2): 41-46.

Anggo, Mustamin, Mohammad Salam, Suhar, and Yulsi Santri. 2014. "Strategi Metakognisi Untuk Meningkatkan Hasil Belajar Matematika." JNPM (Jurnal Nasional Pendidikan Matematika) 5 (1): 84-91. https://doi.org/10.33603/jnpm.v3i2.1995.

Bachtiar, Suhaedir. 2017. “Aktivitas Dan Hasil Belajar Kognitif Siswa Meningkat Melalui Penerapan Model Aktivitas Dan Hasil Belajar Kognitif Siswa Meningkat Melalui Penerapan Model Jigsaw.” Jurnal Biologi \& Pembelajarannya, ISSN: 2406-8659 4 (1): $26-33$.

Bangun, Darwin. 2012. "Hubungan Persepsi Siswa Tentang Perhatian Orang Tua, Kelengkapan Fasilitas Belajar, Dan Penggunaan Waktu Belajar Di Rumah Dengan Prestasi Belajar Ekonomi." Jurnal Ekonomi Dan Pendidikan; ISSN: 1829-8028. https://doi.org/10.21831/jep.v5i1.604.

Dwiningrum, Sayekti, and Ikrar Pramudya. 2016. "Materi Persamaan Garis Lurus Ditinjau Dari Tipe Kepribadian Siswa Kelas VIII SMP Negeri 2 Ngemplak Boyolali.” Prosiding Seminar Matematika Dan Pendidikan Matematika; ISSN: 9786026122209.

Febriani, Putri Siti, and Alit Sarino. 2017. "Dampak Cara Belajar Dan Fasilitas Belajar Dalam Meningkatan Prestasi Belajar Siswa Sekolah Menengah Kejuruan.” Jurnal MANAJERIAL; ISSN: 1412-6613. https://doi.org/10.17509/manajerial.v16i1.10584.

Fitri, Irma. 2017. "Self Efficacy Terhadap Matematika Melalui Pendekatan Aptitude Treatment Interaction." Jurnal Review Pembelajaran Matematika. https://doi.org/10.15642/jrpm.2017.2.2.167-175.

Haryadi, Rahman, and Novi Andriati. 2019. "Pengembangan Game Berbasis Android Untuk Meningkatkan Siswa Sekolah Menengah Pertama the Development of Game Based on Android To Improve Students 'Interest on Integer Arithmetic.” ABSIS: Mathematics Education Journal 1 (November).

Herlina. 2015. "Pengaruh Pendekatan Aptitude Treatment Interaction (ATI) Terhadap Pemahaman Konsep Matematika Siswa Kelas VIII SMP Negeri 25 Pekanbaru.” Primary: Jurnal Pendidikan Guru Sekolah Dasar; ISSN: 2303-1514. https://doi.org/10.33578/jpfkip.v4i1.2726.

Hidajat, Djatmiko, Siti Maghfirotun Amin, and Yusuf Fuad. 2018. "Implementation of Lesson Study in Mathematics Learning Based on Student Cognitive Style." Prosiding Atlantis Press, ISSN: 2352-5401, ISBN: 978-94-6252-593-1, Doi: 10.2991/Icase-18.2018.23, Vol. 175175 (Icase): 84-87.

Hidajat, Djatmiko, Andhika Ayu Wulandari, and Dewi Susilowati. 2018. "Pengaruh Penggunaan Miniatur Mobil Terhadap Prestasi Belajar Matematika." Edudikara, ISSN: 2541-0261 3 (1): 14-22.

Kiswanto, Ulfiani Rahman, and Sri Sulasteri. 2015. "Deskripsi Pemahaman Konsep Materi Geometri Ditinjau Dari Kepribadian Sensing Dan Intuition Pada Siswa Kelas IX SMP N 33 Makassar." MaPan: Jurnal Matematika Dan Pembelajaran; ISSN: 2581-172X.

Kurniawan, Didik, and Dhoriva Urwatul Wustqa. 2014. "Pengaruh Perhatian Orangtua, Motivasi Belajar, Dan Lingkungan Sosial Terhadap Prestasi Belajar Matematika Siswa SMP.” Jurnal Riset Pendidikan Matematika; ISSN: 2356-2684. https://doi.org/10.21831/jrpm.v1i2.2674.

Lestari, Witri. 2017. "Pengaruh Kemampuan Awal Matematika Dan Motivasi Belajar Terhadap Hasil Belajar Matematika.” Jurnal Analisa; ISSN: 2549-5135. 
https://doi.org/10.15575/ja.v3i1.1499.

Masni, Masni. 2019. "Pengaruh Bakat Numerik Dan Kecerdasan Logis Matematis Terhadap Hasil Belajar Siswa Kelas VIII SMPN 3 Langsa." Jurnal Ilmiah Pendidikan Matematika Al Qalasadi; ISSN: 2579-9185. https://doi.org/10.32505/qalasadi.v2i2.794.

Nurhidayah, D. A. 2015. "Pengaruh Motivasi Berprestasi Dan Gaya Belajar Terhadap Prestasi Belajar Siswa Pada Mata Pelajaran Matematika SMP.” Jurnal Dimensi Pendidikan Dan Pembelajaran. https://doi.org/http://dx.doi.org/10.24269/dpp.v3i2.83.

Rachman, Rizal, and Amirul Mukminin. 2018. "Penerapan Metode Certainty Factor Pada Sistem Pakar Penentuan Minat Dan Bakat Siswa SD." Khazanah Informatika: Jurnal Ilmu Komputer Dan Informatika; ISSN: 2621-038X. https://doi.org/10.23917/khif.v4i2.6828.

Sawiji, Hery, Trisno Martono, and Ridaul Inayah. 2013. "Pengaruh Kompetensi Guru, Motivasi Belajar Siswa, Dan Fasilitas Belajar Terhadap Prestasi Belajar Mata Pelajaran Ekonomi Pada Siswa Kelas XI IPS SMA Negeri.” Jurnal Pendidikan Insan Mandiri.

Sembiring, Rosali Br, and . Mukhtar. 2013. "Strategi Pembelajaran Dan Minat Belajar Terhadap Hasil Belajar Matematika.” Jurnal Teknologi Pendidikan (JTP); ISSN: 1979-6692. https://doi.org/10.24114/jtp.v6i2.4996.

Styawan, Sili Wijak, Dewi Susilowati, and Andhika Ayu Wulandari. 2019. "Pengaruh Model Pembelajaran Kooperatif Tipe Snowball Throwing Terhadap Prestasi Belajar Matematika." ABSIS: Mathematics Education Journal 1 (1). https://doi.org/10.32585/absis.v1i1.308.

Subianto, Jito. 2013. "Peran Keluarga, Sekolah, Dan Masyarakat Dalam Pembentukan Karakter Berkualitas." Edukasia : Jurnal Penelitian Pendidikan Islam; ISSN: 1907-7254. https://doi.org/10.21043/edukasia.v8i2.757.

Supardi, A. 2014. "Penggunaan Multimedia Interaktif Sebagai Bahan Ajar Suplemen Dalam Peningkatan Minat Belajar." Jurnal Pendas; ISSN: 2354-9580. https://doi.org/10.30659/pendas.1.2.161=167.

Tamara, Riana Monalisa. 2016. "Peranan Lingkungan Sosial Terhadap Pembentukan Sikap Peduli Lingkungan Peserta Didik Di SMA Negeri Kabupaten Cianjur.” Jurnal Geografi Gea; ISSN: 1412-0313. https://doi.org/10.17509/gea.v16i1.3467.

Widayanti, Lilis. 2016. "Deskripsi Level Kemampuan Siswa SMP Dengan Tipe Kepribadian Cenderung Introvert Dalam Menyelesaikan Masalah Matematika.” Jurnal Edukasi; ISSN: 2443-0455. 

